\title{
Zika virus infection in a traveller returning from the Maldives, June 2015
}

EM Korhonen ${ }^{1}$, E Huhtamo ${ }^{1}$, T Smura $^{1}$, H Kallio-Kokko ${ }^{12}$, M Raassina ${ }^{3}$, 0 Vapalahti ${ }^{12} 4$

1. Department of Virology, Medicum, Faculty of Medicine, University of Helsinki, Helsinki, Finland

2. Department of Virology and Immunology, Helsinki University Central Hospital Laboratory (HUSLAB), Helsinki, Finland

3. Honkaharju hospital, South Karelia Social and Health Care District, Imatra, Finland

4. Department of Veterinary Biosciences, Faculty of Veterinary Medicine, University of Helsinki, Helsinki, Finland

Correspondence: Essi Marjaana Korhonen (essi.m.korhonen@helsinki.fi)

Citation style for this article:

Korhonen E, Huhtamo E, Smura T, Kallio-Kokko H, Raassina M, Vapalahti O. Zika virus infection in a traveller returning from the Maldives, June 2015. Euro Surveill. 2016;21(2): pii=30107. DOI: http://dx.doi.org/10.2807/1560-7917.ES.2016.21.2.30107

Article submitted on 21 December 2015 / accepted on 14 January 2016 / published on 14 January 2016

We report a Zika virus (ZIKV) infection in a patient with fever and rash after returning to Finland from Maldives, June 2015. The patient had dengue virus (DENV) IgG and IgM antibodies but pan-flavivirus RT-PCR and subsequent sequencing showed presence of ZIKV RNA in urine. Recent association of ZIKV with microcephaly highlights the need for laboratory differentiation of ZIKV from DENV infection and the circulation of ZIKV in areas outside its currently known distribution range.

\section{Case report}

A 37-year-old Finnish man returned with his family from a half-a-year work-related stay in the Maldives (in Dhiffushi island, situated in North Male atoll as the capital Malé) to Finland 16 June 2015, without any stopovers elsewhere. Two days later he became ill with flulike prodrome, mild fever and rash in the face and trunk, as well as ocular pain and arthralgia; the symptoms alleviated after a few days. He contacted occupational health and due to suspicion of dengue, a serum sample was taken 24 June, and it was positive for dengue virus IgG (titer 1:1,280, in-house immunofluorescence assay (IFA) test) and IgM (1.9/ cut-off 1.0, Dengue Virus IgM Capture DxSelect ELISA, Focus Diagnostics, USA), but negative for dengue virus (DENV) non-structural (NS) 1 antigen (Dengue NS1 Ag Strip Bio-Rad, France). Along with the serum sample, a urine sample taken on 25 June, the following day, was received for flavivirus RNA detection using a real-time pan-flavivirus NS5 nested RT-PCR [1,2]. RNA from serum and urine samples was extracted using QIAamp Viral RNA Mini Kit (Qiagen).

From the urine (but not the serum) an amplification product was detected and subsequently sequenced (16obp excluding primers, available from the authors upon request). $A$ BLAST search identified the sequence as Zika virus (ZIKV) identical to Asian lineage strains originating from Easter Island 2014 [3], French Polynesia 2013 (GenBank KJ776791), Brazil 2015 (GenBank KU321639) and Thailand 2013 [4] and in phylogenetic analyses the sequence clustered with these strains (Figure). A PCR contamination in the laboratory is further ruled out as no work with ZIKV has ever been conducted, or any positive samples analysed previously in the laboratory - or in the country as a whole.

The Asian cluster is shown in red and African clusters as green and blue. Posterior probabilities are shown only for basal nodes. All ZIKV sequences were downloaded from GenBank (5.1.2016) and sequences overlapping the partial NS 5 gene sequence were included in the analysis. The sequences were aligned using ClustalW algorithm implemented in MEGA version 6. For the sake of clarity, the identical sequences from Easter Island were removed from the data set. The best-fit substitution model was sought using MEGA version 6. The phylogenetic tree was constructed using Bayesian Monte Carlo Markov Chain (MCMC) method implemented in BEAST version 1.8.0 using Tamura-Nei $(\mathrm{TN} 93+\mathrm{G})$ model of substitution, strict molecular clock and constant population size demographic model. The Bayesian analysis was run for 50 million states and sampled every 1000 states. Posterior probabilities were calculated with a burn-in of 5 million states and checked for convergence using Tracer version 1.6.

\section{Investigation of family members}

Similar disease and mosquitoes were frequently reported in the area at the beginning of the rainy season and generally interpreted as dengue. The patient's wife had experienced a mild febrile illness a couple of weeks before departure. Serum samples obtained on 8 July, two weeks after confirmation of Zika virus in our patient, from the patient's wife and three children all of less than 10 years of age, were negative for flavivirus in pan-flavivirus $\mathrm{NS}_{5}$ nested RT-PCR. The children were also DENV seronegative, but the wife had low positive DENV IgG titer (1:20) and low positivity (1.3/ cut-off 1.0, Dengue Virus IgM Capture DxSelect ELISA, Focus Diagnostics, USA) in DENV IgM test. 
Maximum clade credibility tree of partial Zika virus NS5 sequences

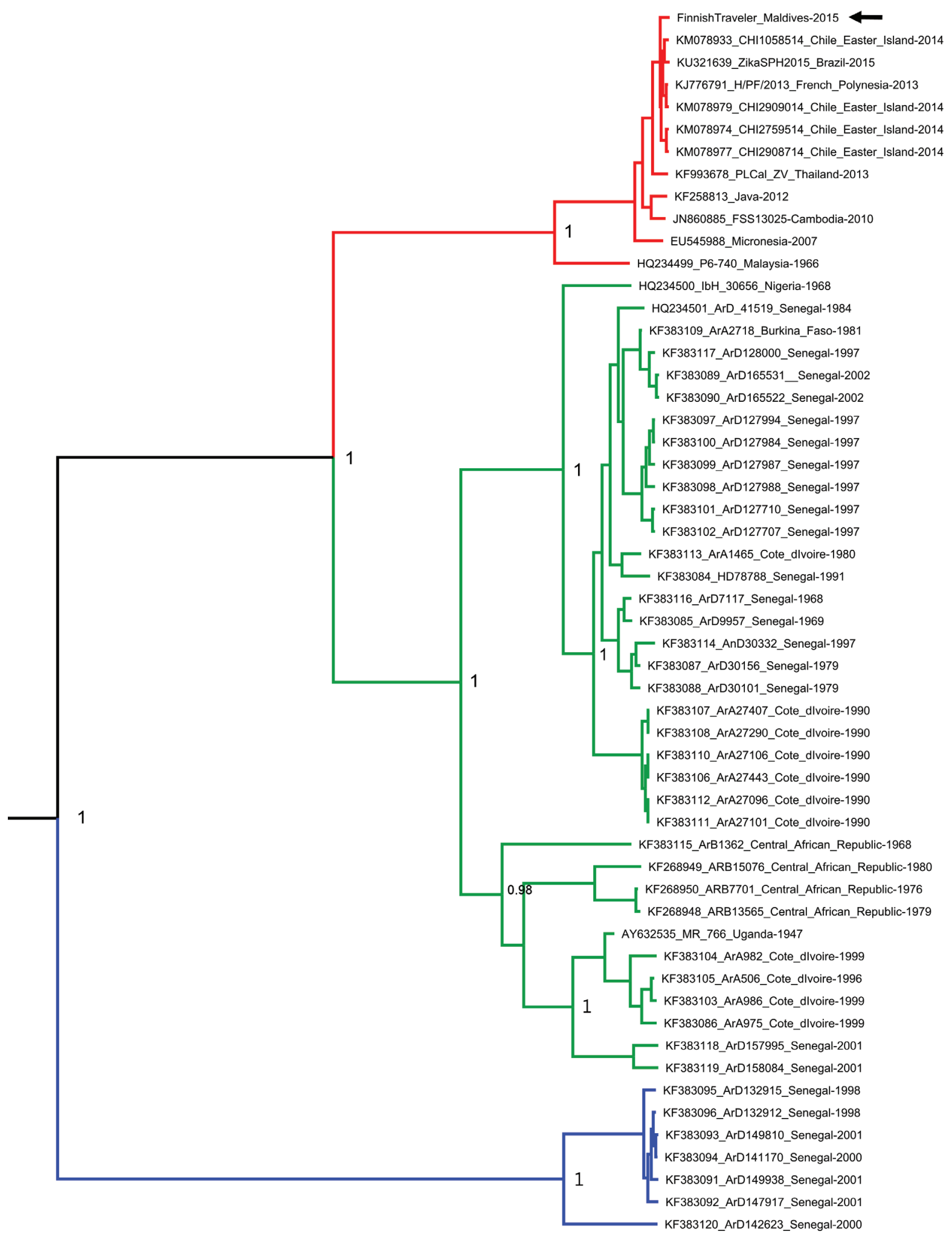

The Asian cluster is shown in red and African clusters as green and blue. Posterior probabilities are shown only for basal nodes. All ZIKV sequences were downloaded from GenBank (5.1.2016) and sequences overlapping the partial NS5 gene sequence were included in the analysis. The sequences were aligned using ClustalW algorithm implemented in MEGA version 6. For the sake of clarity, the identical sequences from Easter Island were removed from the data set. The best-fit substitution model was sought using MEGA version 6 . The phylogenetic tree was constructed using Bayesian Monte Carlo Markov Chain (MCMC) method implemented in BEAST version 1.8.0 using Tamura-Nei (TN93+G) model of substitution, strict molecular clock and constant population size demographic model. The Bayesian analysis was run for 50 million states and sampled every 1000 states. Posterior probabilities were calculated with a burn-in of 5 million states and checked for convergence using Tracer version 1.6. 
TABLE

Verified acute Zika virus infections from South/Southeast Asia, 1977-2015

\begin{tabular}{|l|c|c|c|}
\hline Country of origin & Year & Number of patients & Reference \\
\hline Indonesia & $1977-1978$ & 7 & {$[27]$} \\
\hline & $2013-2015$ & 2 & {$[31,32]$} \\
\hline Cambodia & 2010 & 1 & {$[28]$} \\
\hline Philippines & 2012 & 1 & {$[29]$} \\
\hline Thailand & $2012-2014$ & 10 & {$[4,23,30,33]$} \\
\hline Malaysia & 2014 & 1 & {$[22]$} \\
\hline
\end{tabular}

\section{Background}

ZIKV is a mosquito-borne flavivirus originally isolated in Uganda, 1947 [5]. ZIKV was associated with mild febrile disease and maculo-papular rash in tropical Africa and some areas of South East Asia. Since 2007 ZIKV has caused several outbreaks outside its former distribution area in islands of the Pacific Ocean: in 2007 on Yap island (Federated States of Micronesia) [6] and since 2013-14 in French Polynesia [7,8]. Since 2015, outbreaks have been reported for the first time in South America (Brazil, Columbia) [9,10]. Two lineages of ZIKV, an African (subdivided to West African and East African) and Asian lineage, which emerged in the Pacific and the Americas, respectively, have been identified on the basis of NS5 gene sequences [11].

The main transmission occurs in an urban cycle similar as for dengue and chikungunya, with Aedes (Stegomyia) mosquitoes as vectors [12]. Probable sexual transmission has been associated with ZIKV infection [13] and ZIKV has been isolated, and ZIKV RNA detected from semen samples [14]. Also transplacental transmission of ZIKV during childbirth has been reported in the French Polynesian outbreak [15].

Association with Guillain-Barré syndrome and more recently to an emerging epidemic of congenital microcephaly have increased the public health impact of ZIKV infections $[16,17]$.

\section{Discussion and conclusions}

As in our case, the DENV serology may be positive in ZIKV patients due to cross-reactions between other flaviviruses, and the ZIKV-specific RNA detection methods or sequencing are best for confirmation. The RT-PCR positivity from urine but not serum may suggest that urine is better as a sample material for RNA detection of ZIKV, and indeed the viral load in urine has been shown to be higher and detectable for a longer period, as compared to serum [18] in parallel to dengue [19]. Our patient was found negative in DENV NS1 Ag test, which in most DENV patients is positive during the acute phase [20] yet a negative NS1 result does not exclude DENV infection.
The short sequence obtained from the patient confirmed the etiology of the infection as Zika virus and suggested that the virus strain present in Maldives is of the Asian lineage of ZIKV, and indistinguishable within the amplified short fragment from the epidemic strains reported from e.g. Easter Island and Brazil. Yet, as we have so far been able to sequence only a short part of the NS5 gene, more sequence information is evidently needed.

ZIKV is an emerging arbovirus and it seems to fit well to the transmission cycles of DENV and CHIKV [21], which both have been earlier detected from the Maldives. ZIKV infections have earlier been imported from Asia, South America, French Polynesia and the Caribbean to Europe [22-26]. In Asia, there have been no previous verified ZIKV cases anywhere near Maldives (Table).

With this demonstration of ZIKV transmission in the Maldives, it remains to be elucidated if the circulation of ZIKV is already widespread in the area or geographical vicinity, as clinical manifestations of DENV, CHIKV and ZIKV as well as serological test results for DENV and ZIKV may be similar, or a risk of a larger Zika epidemic remains a possible future threat. The most prevalent symptoms associated with ZIKV, based on the reports from cases transmitted in Asia, are fever, rash, gastrointestinal symptoms, conjunctivitis, arthralgia, sore throat, headache and myalgia $[4,22,23,27-33]$. The recent potential associations of ZIKV with microcephaly and Guillain-Barré syndrome $[16,17]$ highlight the need for ZIKV recognition and detection. The differentiation of DENV and ZIKV infections is a challenge for both clinicians and diagnostic laboratories.

\section{Acknowledgements}

Authors thank Minna Ulmanen and Kirsti Räihä for technical assistance. We acknowledge CSC - IT Center for Science Ltd. (Espoo, Finland) for the allocation of computational resources. We thank Helsinki University Hospital Funds (TYH 2014251), Academy of Finland and Sigrid Juselius Foundation for financial support.

Conflicts of interest

None declared.

\section{Authors' contributions}

Wrote the manuscript: EMK, EH, TS, HKK, MR and OV; performed laboratory investigations: EMK, EH; performed phylogenetic analyses: EH, TS; managed the patient: MR; collected diagnostic and clinical data HKK, MR, OV.

\section{References}

1. Moureau G, Temmam S, Gonzalez JP, Charrel RN, Grard G, de Lamballerie X. A real-time RT-PCR method for the universal detection and identification of flaviviruses.Vector Borne Zoonotic Dis. 2007;7(4):467-77. DOI: 10.1089/vbz.2007.0206 PMID: 18020965

2. Moureau G, Ninove L, Izri A, Cook S, De Lamballerie X, Charrel RN. Flavivirus RNA in phlebotomine sandflies.Vector Borne 
Zoonotic Dis. 2010;10(2):195-7. DOI: 10.1089/vbz.2008.0216 PMID: 19492949

3. Tognarelli J, Ulloa S, Villagra E, Lagos J, Aguayo C, Fasce R, et al. A report on the outbreak of Zika virus on Easter Island, South Pacific, 2014. Arch Virol. 2015.

4. Fonseca K, Meatherall B, Zarra D, Drebot M, MacDonald J, Pabbaraju K, et al. First case of Zika virus infection in a returning Canadian traveler. Am J Trop Med Hyg. 2014;91(5):1035-8. DOI: 10.4269/ajtmh.14-0151 PMID: 25294619

5. Dick GW, Kitchen SF, Haddow AJ. Zika virus. I. Isolations and serological specificity.Trans R Soc Trop Med Hyg. 1952;46(5):509-20. DOI: 10.1016/0035-9203(52)90042-4 PMID: 12995440

6. Duffy MR, Chen TH, Hancock WT, Powers AM, Kool JL, Lanciotti RS, et al. Zika virus outbreak on Yap Island, Federated States of Micronesia. N Engl J Med. 2009;360(24):2536-43. DOI: 10.1056/NEJMoao805715 PMID: 19516034

7. Cao-Lormeau VM, Roche C, Teissier A, Robin E, Berry AL, Mallet HP, et al. Zika virus, French polynesia, South pacific, 2013. Emerg Infect Dis. 2014;20(6):1085-6. DOI: 10.3201/ eid2006.140138 PMID: 24856001

8. Musso D, Nilles EJ, Cao-Lormeau VM. Rapid spread of emerging Zika virus in the Pacific area.Clin Microbiol Infect. 2014;20(10):0595-6. DOI: 10.1111/1469-0691.12707 PMID: 24909208

9. Campos GS, Bandeira AC, Sardi SI. Zika Virus Outbreak, Bahia, Brazil.Emerg Infect Dis. 2015;21(10):1885-6. DOI: 10.3201/ eid2110.150847 PMID: 26401719

10. Zika virus outbreaks in the Americas. Wkly Epidemiol Rec. 2015;90(45):609-10.PMID: 26552108

11. Lanciotti RS, Kosoy OL, Laven JJ, Velez JO, Lambert AJ, Johnson AJ, et al. Genetic and serologic properties of Zika virus associated with an epidemic, Yap State, Micronesia, 2007. Emerg Infect Dis. 2008;14(8):1232-9. DOI: 10.3201/ eid1408.080287 PMID: 18680646

12. Hayes EB. Zika virus outside Africa.Emerg Infect Dis. 2009;15(9):1347-50. DOI: 10.3201/eid1509.090442 PMID: 19788800

13. Foy BD, Kobylinski KC, Chilson Foy JL, Blitvich BJ, Travassos da Rosa A, Haddow AD, et al. Probable non-vector-borne transmission of Zika virus, Colorado, USA. Emerg Infect Dis. 2011;17(5):880-2. DOI: 10.3201/eid1705.101939 PMID: 21529401

14. Musso D, Roche C, Robin E, Nhan T, Teissier A, Cao-Lormeau VM. Potential sexual transmission of Zika virus. Emerg Infect Dis. 2015;21(2):359-61. DOI: 10.3201/eid2102.141363 PMID: 25625872

15. Besnard M, Lastere S, Teissier A, Cao-Lormeau V, Musso D. Evidence of perinatal transmission of Zika virus, French Polynesia, December 2013 and February 2014. Euro Surveill. 2014;19(13):20751. DOI: 10.2807/1560-7917.ES2014.19.13.20751 PMID: 24721538

16. Oehler E, Watrin L, Larre P, Leparc-Goffart I, Lastere S, Valour $\mathrm{F}$, et al. Zika virus infection complicated by Guillain-Barre syndrome--case report, French Polynesia, December 2013. Euro Surveill. 2014;19(9):20720. DOI: 10.2807/1560-7917. ES2014.19.9.20720 PMID: 24626205

17. European Centre for Disease Prevention and Control (ECDC). Zika virus epidemic in the Americas: potential association with microcephaly and Guillain-Barré syndrome. 10 December 2015. Stockholm: ECDC; 2015 . Available from: http://ecdc.europa.eu/ en/publications/Publications/zika-virus-americas-associationwith-microcephaly-rapid-risk-assessment.pdf.

18. Gourinat AC, O'Connor O, Calvez E, Goarant C, DupontRouzeyrol M. Detection of Zika virus in urine.Emerg Infect Dis. 2015;21(1):84-6. DOI: 10.3201/eid2101.140894 PMID: 25530324

19. Korhonen EM, Huhtamo E, Virtala AM, Kantele A, Vapalahti 0 . Approach to non-invasive sampling in dengue diagnostics: exploring virus and NS1 antigen detection in saliva and urine of travelers with dengue.J Clin Virol. 2014;61(3):353-8. DOI: 10.1016/j.jcv.2014.08.021 PMID: 25242312

20. Erra EO, Korhonen EM, Voutilainen L, Huhtamo E, Vapalahti 0 , Kantele $A$. Dengue in travelers: kinetics of viremia and NS1 antigenemia and their associations with clinical parameters.PLoS ONE. 2013;8(6):e65900. DOI: 10.1371/journal. pone.0065900 PMID: 23755291

21. Musso D, Cao-Lormeau VM, Gubler DJ. Zika virus: following the path of dengue and chikungunya?Lancet. 2015;386(9990):2434. DOI: 10.1016/S0140-6736(15)61273-9 PMID: 26194519

22. Tappe D, Nachtigall S, Kapaun A, Schnitzler P, Günther S, Schmidt-Chanasit J. Acute Zika virus infection after travel to Malaysian Borneo, September 2014.Emerg Infect Dis. 2015;21(5):911-3. DOI: 10.3201/eid2105.141960 PMID: 25898277
23. Tappe D, Rissland J, Gabriel M, Emmerich P, Gunther S, Held G, et al. First case of laboratory-confirmed Zika virus infection imported into Europe, November 2013. Euro Surveill. 2014;19(4):20685. DOI: 10.2807/1560-7917.ES2014.19.4.20685 PMID: 24507467

24. Zammarchi L, Stella G, Mantella A, Bartolozzi D, Tappe D, Günther S, et al. Zika virus infections imported to Italy: clinical, immunological and virological findings, and public health implications. J Clin Virol. 2015;63:32-5. DOI: 10.1016/j. jcv.2014.12.005 PMID: 25600600

25. Zammarchi L, Tappe D, Fortuna C, Remoli ME, Günther $\mathrm{S}$, Venturi $\mathrm{G}$, et al. Zika virus infection in a traveller returning to Europe from Brazil, March 2015. Euro Surveill. 2015;20(23):21153. DOI: $10.2807 / 1560-7917 . E S 2015 \cdot 20.23 \cdot 21153$ PMID: 26084316

26. Malvy D, Duvignaud A. Zika virus - Americas (01) - France ex Martinique.ProMed; 2016. http://www.promedmail.org. Archive no 20160108.3921447. Available from: http://www. promedmail.org

27. Olson JG, Ksiazek TG, Suhandiman, Triwibowo . Zika virus, a cause of fever in Central Java, Indonesia.Trans R Soc Trop Med Hyg. 1981;75(3):389-93. DOI: 10.1016/0035-9203(81)90100-0 PMID: 6275577

28. Heang V, Yasuda CY, Sovann L, Haddow AD, Travassos da Rosa AP, Tesh RB, et al. Zika virus infection, Cambodia, 2010. Emerg Infect Dis. 2012;18(2):349-51. DOI: 10.3201/eid1802.111224 PMID: 22305269

29. Alera MT, Hermann L, Tac-An IA, Klungthong C, Rutvisuttinunt W, Manasatienkij W, et al. Zika virus infection, Philippines, 2012. Emerg Infect Dis. 2015;21(4):722-4. DOI: 10.3201/ eid2104.141707 PMID: 25811410

30. Buathong R, Hermann L, Thaisomboonsuk B, Rutvisuttinunt W, Klungthong C, Chinnawirotpisan P, et al. Detection of Zika Virus Infection in Thailand, 2012-2014. Am J Trop Med Hyg. 2015;93(2):380-3. DOI: 10.4269/ajtmh.15-0022 PMID: 26101272

31. Kwong JC, Druce JD, Leder K. Zika virus infection acquired during brief travel to Indonesia.Am J Trop Med Hyg. 2013;89(3):516-7. DOI: 10.4269/ajtmh.13-0029 PMID: 23878182

32. Leung GH, Baird RW, Druce J, Anstey NM. Zika Virus Infection in Australia Following a Monkey Bite in Indonesia.Southeast Asian J Trop Med Public Health. 2015;46(3):460-4.PMID: 26521519

33. Shinohara K. Zika Virus - Japan ex Thailand. ProMed; 2014. http://www.promedmail.org Archive no. 20140823.2716731. Available from: http://www.promedmail.org

\section{License and copyright}

This is an open-access article distributed under the terms of the Creative Commons Attribution (CC BY 4.0) Licence. You may share and adapt the material, but must give appropriate credit to the source, provide a link to the licence, and indicate if changes were made.

This article is copyright of the authors, 2016. 